http://journal.uinsgd.ac.id/index.php/biodjati

\title{
EFFECT OF WATER TEMPERATURE TO SURVIVAL AND DEVELOPMENT OF LARVAE OF TWO LOCAL Aedes aegypti STRAINS
}

\author{
Ramadhani Eka Putra*1, Gunadi Trinuroni²
}

Received : December 20, 2019

Accepted : February 28, 2019

DOI: 10.15575/biodjati.v4i1.3843

${ }^{1,2}$ School of Life Sciences and Technology, Institut Teknologi Bandung.

Jl. Ganesha No. 10, Bandung 40132

e-mail:

*lramadhani@sith.itb.ac.id

²unadi_rino@ymail.com

*Corresponding author
Abstract. Global warming has been reported in last decades. Changes in average Earth's temperature may affect the physiology of many insect species, especially the ones which act as a human disease vector, like Aedes aegypti. In this study, the effect of increasing water temperature on physiological components related to development period, sex ratio, and body size of two distinctively strains, VCRU (Vector Control Research Unit) and Pangandaran. Thirty larvae of each strain kept inside distilled water with the temperature of $25^{\circ} \mathrm{C}$, $27^{\circ} \mathrm{C}, 30^{\circ} \mathrm{C}, 33^{\circ} \mathrm{C}, 35^{\circ} \mathrm{C}, 40^{\circ} \mathrm{C}$ which replicated three times. Observations were conducted until all larvae metamorphed into adults or all larvae dead. Development rate and time were analyzed by frequency dependent mean. The result showed that the optimum temperature for larvae development of VCRU strain was $27-30^{\circ} \mathrm{C}$ with a survival rate of $84 \%$ while it was $30^{\circ} \mathrm{C}$ for Pangandaran strain, with the survival rate of $83 \%$. Larvae of both strains showed $100 \%$ mortality rate when kept inside a container with water temperature exceed $33^{\circ} \mathrm{C}$. Both strains showed the highest and the lowest male:female ratio at similar water temperature which were $33^{\circ} \mathrm{C}$ and $30^{\circ} \mathrm{C}$, respectivelly. Highest and lowest ratio of VCRU was 1.25 and 0.6, respectively, while it was 1.4 and 0.6 for Pangandaran. In general, larvae lived in increasing water temperature showed reducing wing width.

Keywords: Aedes aegypti, development, sex ratio, survivorship, water temperature

\section{Citation}

Putra, R. E. \& Trinuroni, G. (2019). Effect of Water Temperature to Survival and Development of Larvae of Two Local Aedes aegypti Strains. Jurnal Biodjati, 4(1), 40-49

\section{INTRODUCTION}

In the last decades, the climate condition showed the trend of increasing mean temperature of Earth's surface (Revich et al., 2012; Bai et al., 2013). It has been forecasted that the average temperature of the Earth's surface, by the end of the $21^{\text {st }}$ century, will increase by 1-6. $4^{\circ} \mathrm{C}$ (IPCC, 1995; Githeko et al., 2000).

Warming of atmosphere and surface of the earth could affect the variety of physical
(Parry et al., 2007) and biological systems (Githeko et al., 2000; Parry et al., 2007). Changes in both physical and biological may determine the their habitats of many arthropod species (Van Lieshout et al., 2004) which some of them, like mosquitoes, acts as human disease vector (Reiter, 2001).

One of the most known mosquito species, due to its competency as a vector of some of the most deadliest human diseases, is Aedes aegypti (Gubler et al., 1995; Scott et al., 1997; 


\section{Jurnal Biodjati 4(1):40-49, May 2019 \\ JURNAL BIDDJATI}

http://journal.uinsgd.ac.id/index.php/biodjati

Lourenco-de-Oliveira et al., 2002; Nene et al., 2007; Morison et al., 2008). This species spend their early stage in the aquatic habitat and their distribution and physiology are highly effect by physical condition of their aquatic habitat (Bar-Zeev, 1958; Rueda et al., 1990). Reports showed that water temperature less than $10^{\circ} \mathrm{C}$ prevent the development (Slosek, 1986; Hopp \& Foley, 2001). Increasing water temperature, at the optimum range, resulting in (1) shorter development time (Bayoh \& Lindsay, 2003, 2004; Yang et al., 2009; Costa et al., 2010; Couret et al., 2014), (2) virus incubation period (Focks et al., 2000, Hopp \& Foley, 2001), (3) change the sex ration of adult mosquitoes (Tun-Lin, 2000; Mohamed $\&$ Chadee, 2011) and (4) size of adult mosquitoes (Reisen et al., 1984; Siddiqui et al., 1976; Tun-Lin et al., 2000; Schneider et al., 2004).

The most prevalent virus spread by this species is Dengue Fever (DF) which estimated the worldwide number of annual cases is 100 million (Bhatt et al., 2013). In Indonesia, the total number of death caused by this disease could reach 1000 death per year (Ahmad et al., 2007; Kemenkes, 2016).

The effect of the water temperature to the life cycle of Ae. aegypti have been investigated in many regions (Bar-Zeev, 1958; Keirans \& Fay, 1968; Rueda et al., 1990; Kamimura et al., 2002; Mohammed \& Chadee, 2011; Richardson et al., 2011). These studies provided baseline information to develop future strategies to regulate ecobiology of $A e$. aegypti at natural habitat and other habitats near human dwelling (Williams et al., 2014; Campbell et al., 2015; Marinho et al., 2016; Zapletal et al., 2018).

Unfortunately, similar study quite rare in Indonesia where variation in ecological condition and anthropogenic stress caused mosquitoes had developed several strains which varied in physiological characterictics.
In this study, we observed the effect of water temperature to development period, sex ratio, and size of two Ae. aegypti strains, VCRU (a lab strain) and Pangandaran (field strain).

\section{MATERIALS AND METHODS}

\section{Research Period}

The study was conducted at Toxicology and Entomology Laboratory of School of Life Sciences and Technology, Indonesia. The average room temperature was $23-27^{\circ} \mathrm{C}$ with average humidity about $75-90 \%$.

\section{Mosquitoes}

In this study, two mosquito strains were appliedasaresearch subject, namely VCRUand Pangandaran Strains. VCRU (Vector Control Research Unit) was originated from Universiti Sains Malaysia which kept as standard strain at Laboratory of Entomology, School of Life Sciences and Technology, Institut Teknologi Bandung. On the other hand, Pangandaran Strain (PS) was originated from Pangandaran region, a shore area at south of West Java.

\section{Keeping the Mosquitoes}

400 Mosquito eggs were kept inside a container $(17 \times 12 \times 16 \mathrm{~cm})$ filled with $500 \mathrm{~mL}$ distilled water. 30 hatched larvae collected by pipette and kept inside $250 \mathrm{~mL}$ glass jar filled with $100 \mathrm{~mL}$ distilled water. Larvae were fed ad libitum with commercial fish feed. Jars kept inside water bath with designated temperature. Water changed daily and fresh fish feed added after the water was changed.

\section{Heat Treatment and Mortality}

In this study, larvae of each strain were kept at a water temperature of $25^{\circ} \mathrm{C}, 27^{\circ} \mathrm{C}$, $30^{\circ} \mathrm{C}, 33^{\circ} \mathrm{C}, 35^{\circ} \mathrm{C}, 40^{\circ} \mathrm{C}$. Mortality rate observed at 24 hours and the observation was conducted for all larvae metamorphosed into 


\section{JURNAL BI@DJATI}

http://journal.uinsgd.ac.id/index.php/biodjati

pupae. All treatements were replicated three times.

\section{Measuring the Size of Mosquitoes}

Adult size was determined by measuring length of wing (Packer \& Corbet, 1989; Briegel et al., 1990a,b; Lounibos et al., 1990; Livdahl \& Wiley, 1991; Blackmore \& Lord, 2000; Briegel \& Timmermann, 2001; Armbruster \& Hutchinson, 2002). Studies by Carron (2007) and Petersen et al. (2016) showed the positive correlation between wing length and weight of adult which made this methods as one of the simplest method for rapid measurement of mosquitoes weight.

\section{Data Analysis}

Development duration of Ae. egypti measured by frequency means dependent. Development period was calculated by $1 /$ average of development duration. Sex ratio calculated by dividing a total number of adult male and female. Survivorship calculated by comparing a number of surviving adult mosquitoes and total observed mosquitoes. All data analyzed by Kolmogorov-Smirnov test for normality followed by ANOVA (for normaly distributed data) and Mann-Whitney (for data which not normaly distributed) with confidence level of $\mathrm{P}<0.05$. Tukey post hoc test was applied for data with a significant result.

\section{RESULTS AND DISCUSSION}

\section{Survivorship}

Larvae of both strain unable to live at water temperature above $33^{\circ} \mathrm{C}$ with VCRU strain has the lower survival rate at that temperature. At the lower temperature, there was no difference between both strains (Figure 1).

The result is contradictive with recent studies showed the absence of Ae. aegypti immature in the container with water temperature exceed $32^{\circ} \mathrm{C}$ (Bond \& Fay, 1969; Chadee \& Rahaman, 2000; Chadee, 2003; Hemme et al., 2009). It seems, higher temperature $\left(33^{\circ} \mathrm{C}\right)$ more likely to prevent eggs from hatch and increase the mortality of early instar (Padmanabha et al., 2011). The higher survival rate of Pangandaran strain might be related to the habitat condition of Pangandaran where the average temperature could exceed $35^{\circ} \mathrm{C}$.

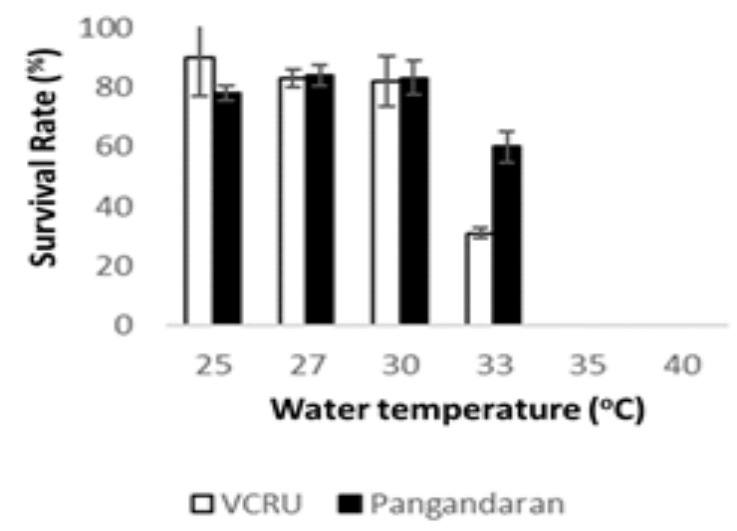

Figure 1. The survival rate of VCRU and Pangandaran strains

\section{Development Duration}

Increasing water temperature reduced the development time of both strains and VCRU strain had slightly shorter development period (ANOVA, $\mathrm{P}>0.05$ ) (Fig.2).

Like another arthropods, insect needs particular temperature range to develop which highly affected by their genetic makeup (Chadee, 2004; Gillot, 2005).

\section{Development Rate}

The highest development rate was recorded at a water temperature of $30^{\circ} \mathrm{C}$. On average, development rate of VCRU was higher than Pangandaran (Fig. 3).

The results supported previous result on the positive correlation between temperature and development rate of mosquito (Rueda et 


\section{Jurnal Biodjati 4(1):40-49, May 2019 \\ JURNAL BIDDJATI}

http://journal.uinsgd.ac.id/index.php/biodjati

al., 1990; Bayoh \& Lindsay, 2003; Loetti et al., 2011, Ciota et al., 2015).

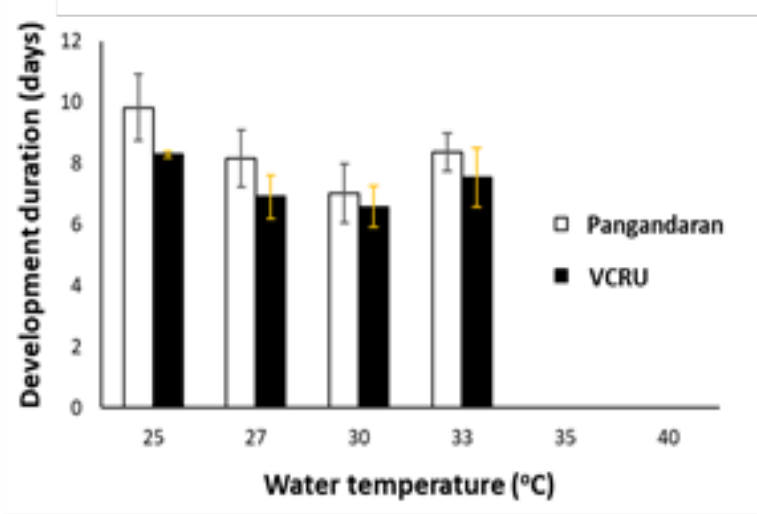

Figure 2. Average development duration of VCRU and Pangandaran

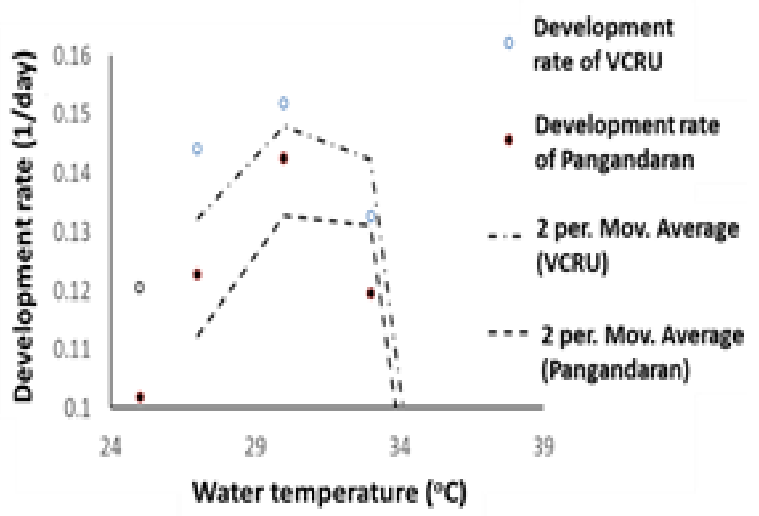

Figure 3. Development rate of Aedes aegypti of VCRU and Pangandaran Strain

\section{Adult Wing Length}

Larvae kept in higher water temperature had shorter wing length. The impact of water temperature to wing width was more prominent in female $(\mathrm{p}<0.05)$ than male $(\mathrm{p}>0.05)$ (Fig. 4).

Lower mosquito size at higher habitat temperature also reported by previous studies (Chambers \& Klowden, 1990; Rueda et al., 1990; Chadee \& Beier, 1997; Gunay et al., 2011).

Shorter wing span of adult is related to shorter development time which has been reported by many previous studies (BarZeev, 1958; Rueda, 1990; Lyimo et al., 1992; Tun Lin et al., 2000; Alto \& Juliano, 2001; Mourya et al., 2004; Mohammed \& Chadee, 2011). Interestingly, the wing length of male and female was quite similar at $30^{\circ} \mathrm{C}$ treatment group. It seems, $30^{\circ} \mathrm{C}$ was the optimum temperature for development for both sexes. Smaller size probably as result of increasing growth efficiency (Rashed \& Mulla, 1989) which allow the larvae to reach critical mass for pupation in shorther time (Atkinson \& Sibly, 1997).

Some studies showed the positive correlation between wing width to reproductive success rate of locating host, fecundity, life span, etc. (Packer \& Corbet, 1989; Briegel, 1990a, 1990b; Lounibos et al., 1990; Livdahl \& Wiley, 1991; Blackmore \& Lord, 2000; Briegel \& Timmermann, 2001; Armbuster \& Hutchinson, 2002). Since both strains could be considered as susceptible strain, the increasing temperature could produce negative implication to their population in laboratory and field.
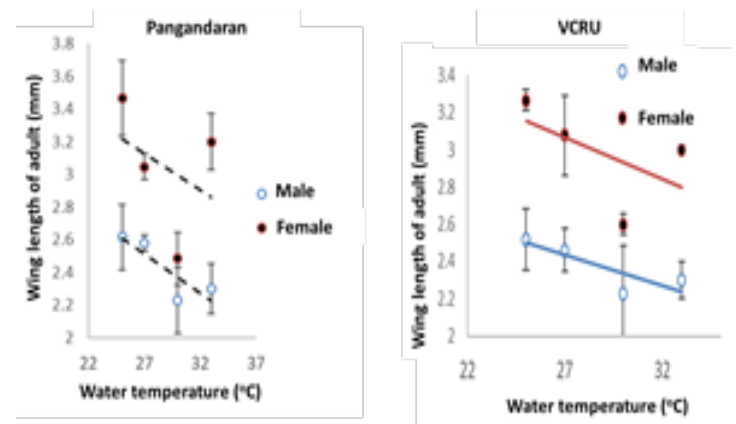

Figure 4. Comparison of Average wing width between male and female adult Aedes aegypti of Pangandaran and VCRU strain reared at different water temperature.

\section{Sex Ratio (Male : Female)}

This study showed the impact of water temperature on male/female $(\mathrm{M} / \mathrm{F})$ sex ratios. 


\section{Jurnal Biodjati 4(1):40-49, May 2019 \\ JURNAL BI@DJATI}

http://journal.uinsgd.ac.id/index.php/biodjati

The Lowest $\mathrm{M} / \mathrm{F}$ ratio was recorded at $30^{\circ} \mathrm{C}$ and the highest at $33^{\circ} \mathrm{C}$ (Fig. 5).

The result was similar to another study in India (Mourya et al., 2004). There was no correlation between habitat temperature and $\mathrm{M} / \mathrm{F}$ ratios which identical to previous studies (Bar-Zeev, 1958; Tun-Lin et al., 2000; Mohammed \& Chadee, 2011).

However, higher $\mathrm{M} / \mathrm{F}$ ratio recorded at higher temperature was disagree with the pattern of $\mathrm{M} / \mathrm{F}$ ratio reported by previous studies (Mourya et al., 2004; Mohammed \& Chadee, 2011). It has been hypothesized that mosquito sex ratio is modulated by a meiotic driver which preference to produce more male at specific temperatures (Cha et al., 2006). Thus, there is a possibility that habitat provides selection forces which determine the sex determination which recommended as a further study.

This study showed possible physiological effect of increasing water temperature, which in related to the average environmental temperature, to field and lab mosquitoes. Both showed some significant effect in reducing the development time, development rate and size of adult mosquitoes. This condition may created change in term of mosquito and disease distribution. The lower development time and rate could create more overlapping generation, a more rapid population proliferation and increase rate of mutation through mating among those population. On the other hand, the smaller mosquito may lead to more concentrate mosquito populations due to limitation in dispersal and available energy of smaller mosquitoes. Further studies are required to observe the effect increasing water temperature to virulence of DF virus to provide a better understanding of possible DF outbreak in the future due to global warming.

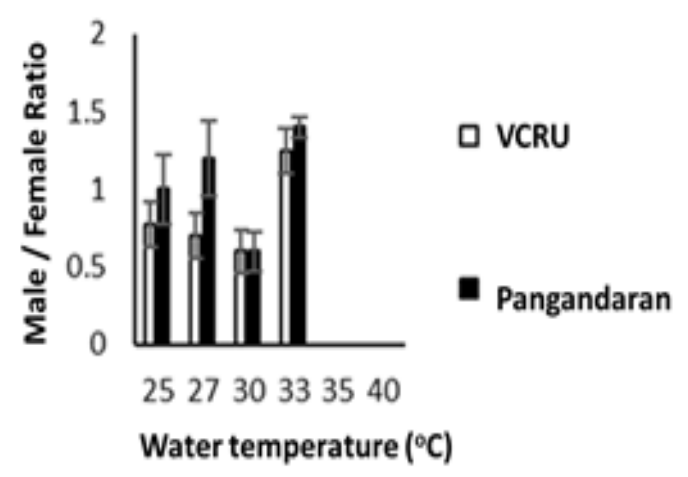

Figure 5. Male and Female Ratio of VCRU and Pangandaran

\section{REFERENCES}

Ahmad, I., Astari, S. \& Tan, M.(2007). Resistance of Aedes aegypti (Diptera: Culicidae) in 2006 to Pyrethroid Insecticides in Indonesia and its Association with Oxidase and Esterase Levels. Pakistan Journal of Biological Sciences, 10(20), 3688-3692.

Alto, B. W. \& Juliano, S. A. (2001). Precipitation and Temperature Effects on Populations of Aedes albopictus (Diptera: Culicidae): Implications for Range ExPansion. Journal of Medical Entomology, 38, 646-656.

Armbruster, P. \& Hutchinson, R. A. (2002). Pupal Mass and Wing Length as Indicators of Fecundity in Aedes albopictus and Aedes geniculatus (Diptera: Culicidae). Journal of Medical Entomology, 39(4), 699-704.

Atkinson, D. \& Sibly, R. M. (1997). Why are Organisms Usually Bigger in Colder Environments? Making Sense of Life History Puzzle. Trends in Ecology \& Evolution, 12, 235-239.

Bai, L., Morton, L. C. \& Liu, Q. (2013). Climate Change and Mosquito Born-Diseases in China: a Review. Globalization 


\section{Jurnal Biodjati 4(1):40-49, May 2019 \\ JURNAL BI@DIATI}

http://journal.uinsgd.ac.id/index.php/biodjati

and Health, 9, 1-22.

Bar-Zeev, M. (1958). The Effect of Temperature on the Growth Rate and Survival of the Immature Stages of Aëdes aegyp$t i$ (L.). Bulletin of Entomological Research, 49, 157-163.

Bayoh, M. N. \& Lindsay, S. W. (2003). Effect of Temperature on the Development of the Aquatic Stages of Anopheles gambiae sensu stricto (Diptera: Culicidae). Bulletin of Entomological Research, 93, 375-381.

Bayoh, M. N. \& Lindsay, S. W. (2004). Temperature-Related Duration of Aquatic Stages of the Afrotropical Malaria Vector Mosquito Anopheles gambiae in the Laboratory. Medical and Veterinary Entomology, 18, 174-179.

Bhatt, S., Gething, P. W., Brady, O. J., Messina, J. P., Farlow, A. W., Moyes, C. L., Drake, J. M., Brownstein, J. S., Hoen, A. G., Sankoh, O., Myers, M. F., George, D. B., Jaenisch, T., Wint, G. R. W., Simmons, C. P., Scott, T. W., Farrar, J. J. $\&$ Hay, S. I. (2013). The Global Distribution and Burden of Dengue. Nature, 496, 504-507.

Blackmore, M. S. \& Lord, C. C. (2000). The Relationship Between Size and Fecundity in Aedes albopictus. Journal of Vector Ecology, 25, 212-217.

Bond, H. A. \& Fay, R. W. (1969). Factors Influencing Aedes aegypti Occurrence in Containers. Mosquito News, 29, 113-116.

Briegel, H. (1990a). Fecundity, Metabolism, and Body Size in Anopheles (Diptera: Culicidae), Vectors of Malaria. Journal of Medical Entomology, 27, 839-850.

Briegel, H. (1990b). Metabolic Relationship Between Female Body Size, Reserves, and Fecundity of Aedes aegypti. Journal of Insect Physiology, 36, 165-172.

Briegel, H. \& Timmermann, S. E. (2001).
Aedes albopictus (Diptera: Culicidae): Physiological Aspects of Development and Reproduction. Journal of Medical Entomology, 38, 566-571.

Campbell, L. P., Luther, C., Moo-Llanes, D., Ramsey, J. M., Danis-Lozano, R. \& Peterson, A. T. (2015). Climate Change Influences on Global Distributions of Dengue and Chikungunya Virus Vectors. Philosophical Transactions of the Royal Society B Biological Sciences, 370.

Carron, A. (2007). Correlation Between Wing Measurements and Dry Body Weight in Male and Female Ochlerotatus (Ochlerotatus) caspius (Pallas, 1771) (Diptera: Culicidae). Journal of the European Mosquito Control Association, 24, 4-8.

Cha, S.J., Mori, A., Chadee, D. D. \& Severson, D. W. (2006). Cage Trials Using an Endogenousmeiotic Drive Gene in the Mosquito Aedes aegypti to Promote Population Replacement. The American Journal of Tropical Medicine and Hygiene, 74, 62-68.

Chadee, D. D. (2003). Surveillance for the Dengue Vector Aedes aegypti in Tobago, West Indies. Journal of the American Mosquito Control Association, 19, 199-205.

Chadee, D. D. \& Beier, J. C. (1997). Factors Influencing the Duration of Blood-Feeding by Laboratory-Reared and Wild $A e$ des aegypti (Diptera: Culicidae) from Trinidad, West Indies. Annals of Tropical Medicine and Parasitology, 91, 199207.

Chadee, D. D. \& Rahaman, A. (2000). Use of Water Drums by Humans and Aedes aegypti in Trinidad. Journal of Vector Ecology, 25, 28-33.

Chadee, D. D., Williams, F. L. R. \& Kitron, U. (2004). Epidemiology of Dengue Fever 


\section{Jurnal Biodjati 4(1):40-49, May 2019 \\ JURNAL BI@DIATI}

http://journal.uinsgd.ac.id/index.php/biodjati

in Trinidad West Indies: the Outbreak of 1998. Annals of Tropical Medicine and Parasitology, 98, 305-312.

Chambers, G. M. \& Klowden, M. J. (1990). Correlation of Nutritional Reserves with a Critical Mass for Pupation in Larval Aedes aegypti Mosquitos. Journal of the American Mosquito Control Association, 6, 394-399.

Ciota, A. T., Matacchiero, A. C., Kilpatrick, A. M. \& Kramer, L. D. (2015). The Effect of Temperature on Life History Traits of Culex Mosquitoes. Journal of Medical Entomology, 51(1), 55-62.

Costa, E. A. P. A., Santos, E. M. M., Correia, J. C. \& Albuquerque, C. M. R. (2010). Impact of Small Variations in Temperature and Humidity on the Reproductive Activity and Survival of Aedes aegypti (Diptera: Culicidae). Revista Brasileira de Entomologia, 54, 488-493.

Couret, J., Dotson, E. \& Benedict, M. Q. (2014). Temperature, Larval Diet and Density Effects on Development Rate and Survival of Aedes aegypti (Diptera: Culicidae). PLoS One, 9.

Focks, D. A., Brenner, R. J., Hayes, J. \& Daniels, E. (2000). Transmission Thresholds for Dengue in Terms of Aedes aegypti Pupae per Person with Discussion of their Utility in Source Reduction Efforts. The American Journal of Tropical Medicine and Hygiene, 62, 11-18.

Gillott, C. (2005). Entomology Third Edition. Publised by Springer. Dordrecth.

Githeko, A. K., Lindsay, S. W., Confalonieri, U. E. \& Patz, J. A. (2000). Climate Change and Vector-Borne Diseases: a Regional Analysis. Bulletin of the World Health Organization, 78, 1136-1147.

Gubler, D. J. \& Clark, G. G. (1995). Dengue/Dengue Hemorrhagic Fever: the Emergence of a Global Health Problem.
Emerging Infectious Diseases, 1(2), 55 57.

Gunay, F., Alten, B. \& Ozsoy, E. D. (2011). Narrow-Sense Heritability of Body Size and its Response to Different Developmental Temperatures in Culex quinquefasciatus (Say 1923). Journal of Vector Ecology, 36, 348-354.

Hopp, M. J. \& Foley, J. A. (2001). Global-Scale Relationships Between Climate and the Dengue Fever Vector, Aedes aegypti. Climatic Change 48, 441-463.

Hemme, R. R., Tank, J. L., Chadee, D. D. \& Severson, D.W. (2009). Environmental Conditionsin Water Storage Drums and Influences on Aedes aegypti in Trinidad West Indies. Acta Tropica, 112, 59-66.

IPCC (1995). Intergovernmental Panel on Climate Change (IPCC), WMO/UNEP. A Second Assessment Report of the Intergovernmental Panel on Climate Change, 1-73.

Kamimura, K., Matsuse, I. T., Takahashi, H., Komukai, J., Fukuda, T., Suzuki, K., Aratani, M.,Shirai, Y. \& Mogi, M. (2002). Effect of Temperature on the Development of Aedes aegypti and Aedes albopictus. Medical Entomology and Zoology, 53(1), 53-58.

Keirans, J. E. \& Fay, R. W. (1968). Effect of Food and Temperature on Aedes aegypti (L.) and Aedes triseriatus (Say) Larval Development. Mosquito News, 28, 338341.

Kemenkes RI. (2016). Infodatin 2016 (Situasi Demam Berdarah Dengue di Indonesia). Jakarta: Pengolahan Data dan Informasi, Kementerian Kesehatan Republik Indonesia. (in Indonesian)

Livdahl, T. P. \& Wiley, M. S. (1991). Prospects for an Invasion: Competition Between Aedes albopictus and Native Aedes triseriatus. Science, 253, 189-191. 


\section{Jurnal Biodjati 4(1):40-49, May 2019 \\ JURNAL BI@DIATI}

http://journal.uinsgd.ac.id/index.php/biodjati

Loetti, V., Schwiegmann, N. J. \& Burroni, N.E. (2009). Temperature Effect on the Immature Development Time of Culex eduardoi Casal \& Gracia (Diptera: Culicidae). Neotropical Entomology, 40(1), 138-142

Lounibos, L. P., Sua'rez, S., Mene'ndez, Z., Nishimura, N., Escher, R. L., O'Connell, S. M. \& Rey, J. R. (2002). Does Temperature Affect the Outcome of Larval Competition Between Aedes aegypti and Aedes albopictus?. Journal of Vector Ecology, 27, 86-95.

Lourenco-de-Oliveira, R., Honorio, N. A., Castro, M. G., Schatzmayr, H. G., Miagostovich, M. P., Alves, J. C. R., Silva, W. C., Leite, P. J. \& Nogueira, R. M. (2002). Dengue Virus Type 3 Isolation from Aedes aegypti in the Municipality of Nova Iguacu, State of Rio deJaneiro. Memorias do Instituto Oswaldo Cruz, 97, 799-800.

Lyimo, E. O., Takken, W. \& Koella, J. C. (1992). Effects of Rearing Temperature and Larvaldensity on Larval Survival, Age at Pupation and Adult Size of Anopheles gambiae. Entomologia Experimentalis et Applicata, 63, 265-271.

Marinho, R. A., Beserra, E. B., Bezerra-Gusmao, M. A., Porto, V. S., Olinda, R. A., $\&$ dos Santos, C. A. C. (2016). Effects of Temperature on the Life Cycle, ExPansion and Dispersion of Aedes aegypti (Diptera: Culicidae) in Three Cities in Paraiba, Brazil. Journal of Vector Ecology, 41(1), 1-10.

Mohammed, A. \& Chadee, D. D. (2011). Effect of Temperature Regimens of Aedes aegypti (L) (Diptera: Culicidae) Mosquitoes. Acta tropica, 119, 38-43.

Morrison, A. C., Zielinski-Gutierrez, E., Scott, T. W. \& Rosenberg, R. (2008). Defining Challenges and Proposing Solutions for
Control of the Virus Vector Aedes aegypti. PLoS Medicine, 5, 68.

Mourya, D. T., Yadav, P. \& Misra, A. C. (2004). The Effect of Temperature Stress on Immature Stages and Susceptibility of Aedes aegypti Mosquitoes to Chikungunya Virus. The American Journal of Tropical Medicine and Hygiene, 70, 346-350.

Nene, V., Wortman, J. R., Lawson, D., Haas, B., Kodira, C., Tu, Z. J., Sinkins, S. P., Hogenkamp, D. G., Amedeo, P., Arensburger, P., Atkinson, P.W, Bidwell, S., Biedler, J., Birney, E., Bruggner, R. V., Costas, J., Coy, M. R., Crabtree, J., Crawford, M., Debruyn, B., Decaprio, D., Eiglmeier, K., Eisenstadt, E., El-Dorry, H., Gelbart, W. M., Gomes, S. L., Hammond, M., Hannick, L. I., Hogan, J. R., Holmes, M. H., Jaffe, D., Johnston, J. S., Kennedy, R. C., Koo, H., Kravitz, S., Kriventseva, E. V., Kulp, D., Labutti, K., Lee, E., Li, S., Lovin, D. D., Mao, C., Mauceli, E., Menck, C. F., Miller, J. R., Montgomery, P., Mori, A., Nascimento, A. L., Naveira, H. F., Nusbaum, C., O’leary, S., Orvis, J., Pertea, M., Quesneville, H., Reidenbach, K. R., Rogers, Y. H., Roth, C. W., Schneider, J. R., Schatz, M., Shumway, M., Stanke, M., Stinson, E. O., Tubio, J. M., Vanzee, J. P., Verjovski-Almeida, S., Werner, D., White, O., Wyder, S., Zeng, Q., Zhao, Q., Zhao, Y., Hill, C. A., Raikhel, A. S., Soares, M. B., Knudson, D. L., Lee, N. H., Galagan, J., Salzberg, S. L., Paulsen, I. T., Dimopoulos, G., Collins, F. H., Birren, B., Fraser-Liggett, C. M. \& Severson, D. W. (2007). Genome Sequence of Aedes aegypti, a Major Arbovirus Vector. Science, 316, 1718-1723.

Padmanabha, H., Bolker, B., Lord, C. C., Rubio, C. \& Lounibos, L. P. (2011). Food 


\section{Jurnal Biodjati 4(1):40-49, May 2019 \\ JURNAL BI@DIATI}

http://journal.uinsgd.ac.id/index.php/biodjati

Availability Alters the Effects of Larval Temperature on Aedes aegypti Growth. Journal of Medical Entomology, 48(5), 974-984.

Packer, M. J. \& Corbet, P. S. (1989). Size Variation and Reproductive Success of Female Aedespunctor(Diptera: Culicidae). Economic Entomology, 14, 297-309.

Parry, M. L., Canziani, O. F., Palutikof, J., van der Linden, P. J. \& Hanson,C. E. (2007). IPCC, 2007. Climate Change 2007: Impacts, Adaptation and Vulnerability. Contribution of Working Group II to the Fourth Assessment Report of the Intergovernmental Panel on Climate Change. Cambridge: Cambridge University Press, pp 1-976.

Petersen, V., Marchi, M. J., Natal, D., Marreli, M. T., Barbosa, A. C. \& Suesdek, L. (2016). Assessment of the Correlation Between Wing Size and Body Weight in Captive Culex quinquefasciatus. Revista de Sociedade Brasileira de Medicina Tropical, 49(4), 508-51

Rashed, S. S. \& Mulla, M. S. (1989). Factors Influencing Ingestion of Particulate Materials by Mosquito Larvae (Diptera, Culicidae). Journal of Medical Entomology, 26, 210-216.

Richardson, K., Hoffmann, A. A., Johnson, P., Ritchie, S. A. \& Kearney, M. R. (2011). Thermal Sensitivity of Aedes aegypti from Australia: Empirical Data and Prediction of Effects on Distribution. Journal of Medical Entomology, 48, 914-924.

Reisen, W. K., Milby, M. M. \& Bock, M. E. (1984). The Effects of Immature Stress on Selected Events in the Life History of Culex tarsalis. Mosquito News, 44, 385-395.

Reiter, P. (2001). Climate Change and Mosquito Borne Disease. Environmental Health Perspectives, 109, 141-161.
Revich, B., Tokarevich, N. \& Parkinson, A. J. (2012). Climate Changeand Zoonotic Infections in the Russian Arctic. International Journal of Circumpolar Health, 71, 1-8.

Rueda, L. M., Patel, K. J., Axtell, R. C. \& Stinner, R. E. (1990). Temperature-Dependent Development and Survival Rates of Culex quinquefasciatus and Aedes aegypti (Diptera: Culicidae). Journal of Medical Entomology, 27, 892-898.

Schneider, J. R., Morrison, A. C., Astete, H., Scott, T.W.\& Wilson, M.L.(2004). Adult Size and Distribution of Aedes aegyp$t i$ (Diptera: Culicidae) Associated with Larval Habitats in Iquitos, Peru. Journal of Medical Entomology, 41(4), 634-642.

Scott, T. W., Naksathit, A., Day, J. F., Kittayapong, P. \& Edman, J. D. (1997). A Fitness Advantage for Aedes aegypti and the Viruses it Transmits when Females Feed Only on Human Blood. The American Journal of Tropical Medicine and Hygiene, 57, 235-239.

Siddiqui T. F., Aslam, Y. \& Reisen, W. K. (1976). The Effect of Larval Density on Selected Immature and Adult Attributes of Culex tritaeniorhynchus. Tropical Medicine, 18, 195-200.

Slosek, J. (1986). Aedes aegypti Mosquitoes in the Americas: a Review of their Interactions with the Human Population. Social Science and Medicine, 23, 249-257

Tun-Lin, W., Burkot, T. R. \& Kay, B. H. (2000). Effects of Temperature and Larval Diet on Development Rates and Survival of the Dengue Vector Aedes aegypti in North Queensland, Australia. Medical and Veterinary Entomology, 14, 31-37.

Van Lieshout, M., Kovats, R. S., Livermore, M. T. J. \& Martens, P. (2004). Climate Change and Malaria: Analysis 


\section{JURNAL BIDDJATI}

http://journal.uinsgd.ac.id/index.php/biodjati

of the SRES Climate and Socio-Economic Scenarios. Global Environment Change, 14, 87-99

Williams, C. R., Gina, M., Ritchie, S. A., Viennet, E. \& Harley, D. (2014). Bionomic Response of Aedes aegypti to Two Future Climate Change Scenarios in Far North Queensland, Australia: Implications for Dengue Outbreaks. Parasite \& Vectors, 7, 447.

Yang, H. M., Macoris, M. L. G., Galvani, K. C., Andrighetti, M. T. M. \& Wanderley, D. M. (2009). Assessing the Effects of Temperature on the Population of Aedes aegypti, the Vector of Dengue. Epidemiology \& Infection, 137, 1188-1202.
Zapletal, J., Erraguntla, M., Adelman, Z. N., Myles, K. M. \& Lawley, M. A. (2018). Impacts of Diurnal Temperature and Larval Density on Aquatic Development of Aedes aegypti. PLoS ONE, $13(3)$. 